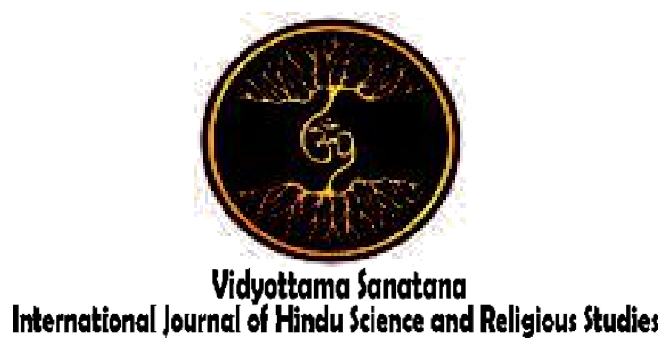

Vol. 3 No. 2 October 2019

\title{
TECHNIQUES AND STRATEGIES FOR HINDU SURVIVAL IN MENJING VILLAGE
}

\author{
By: \\ I Made Wirahadi Kusuma \\ Institut Hindu Dharma Negeri Denpasar \\ E-mail : wirahadikusuma222@yahoo.com
}

\begin{tabular}{|l|l|l} 
Received: August 20, 2019 & Accepted: September 26, 2019 & Published: October 31, 2019 \\
\hline
\end{tabular}

\begin{abstract}
The role of education today is highly essential in the process of social transformation, particularly in relation to respect for pluralistic religious entities. Education as an effort to humanize humans as the aim of religious education which has been specified in Article 2 of Government Regulation No. 55/2007. It is a representative effort in forming better human qualities. Religious education is a pattern of learning dimensions that represent not only education in the formal, informal, or non-formal sense. The religious dimension that guides the community into multicultural life is built on equal right and life. The identical treatment of various differences, both religion and social status of a person is an absolute service that must be provided to everyone, so there is no one-sided discrimination against likes or dislikes, or majority or minority. Disclosure of the dominance of the majority and minority systems in Menjing has become a phenomenon examined in this study which is a struggle for the ideological dimension of the religious system between Hinduism and Islam in Menjing Village.
\end{abstract}

Keywords: Religious Education, Survival, Majority and Minority.

\section{INTRODUCTION}

The role of education today is highly essential in the process of social transformation, particularly in relation to respect for pluralistic religious entities.
Although it is recognized that education does not determine the merits of the development of religious pluralism. However, education as an effort to humanize humans as declared by Napoleon Hill, that: "Education construct 
not only human being but also human becoming" (Redana, 2000). In line with Napoleon Hill's view, education not only develops the ability of human intelligence but also humanizes humans, bearing in mind the functions and objectives of religious education as described in Article 2 of Government Regulation No. 55/2007, which states that: 1) religious education functions to form Indonesian people who have faith and piety, and are able to maintain peace, harmony between religious communities; 2) religious education aims to develop students' abilities in understanding, living, and practicing religious values.

Religious education is a pattern of learning dimensions that represent not only education in the formal, informal, or nonformal sense. Yet, it is more than that, religious education is a pattern of education whose scope is in the field of society with social, cultural, and religious values. The religious dimension that guides the community into multicultural life is built on equal right and life. The identical treatment of various differences, both religion and social status of a person is an absolute service that must be provided to everyone, so there is no one-sided discrimination against likes or dislikes, or majority or minority.

The development of the Hindu community in Menjing is in a minority position compared to the majority of other religious adherents, positioning the community with its religious values as an identity that actually gives a way or becomes a roadblock. The point is different in faith is different in service. The situation formed a discriminatory treatment that occurred during the New Order government, which directed the community in a choice that had major implications for the development of Hinduism in Menjing Village. The education system that has been going on for a long time with a pattern of differentiating people's identities is a huge error in the formation of character education in society. Where the purpose of education is to be able to humanize human beings, it will actually be a struggle in an ideological and identity battle.
The survival of Sradha and Bhakti of the Hindu community, both pseudo and real shows that Hinduism is still maintained and taught in the land of Menjing. Informal and non-formal education carried out in the family and unity of Hindus in Menjing, presents a reinforcement of the character that Hinduism which used to be the initial religious identity they received must be kept and maintained from generation to generation. Religious education as an integrated education pattern is an inheritance of values related to beliefs, knowledge, rituals, experiences, and consequences related to social, cultural, and religious systems in maintaining the existence of Hinduism in Menjing Village.

\section{DISCUSSION}

\subsection{Techniques for the Retention of Hindus in Menjing}

\subsubsection{Construction of Temples as the Centralization of Unification of Hindus People}

The existence of a holy place as a religious activity of religious people is a transcendence relationship between humans and God. This fact is inseparable from the beliefs of religious communities in Indonesia, that the holy place is a medium that is mutually agreed upon as a place to carry out religious activity. In the village of Menjing which is predominantly Muslim, there is also a temple which is a place of worship and gathering of Hindus in simplicity. The temple is Pura Kerta Loka. The existence of this temple is a milestone in the early awakening of the Hindu community in Menjing to be able to slowly rebuild the dimension of religiosity that was once shaken during the reign of the New Order.

The struggle of Hindu figures and people in Menjing in establishing a temple is quite challenging. The struggle that had been under the hegemony and domination of the majority group made them construct a temple as a place of community activity. Where according to Cassirer (1994) the struggle is a process of social learning for the Hindu community in Menjing in its development of 
understanding the social system in society to strengthen mutual communication and social interaction internally. The strengthening and process of the maturation of the religious social system initially started from gathering together by coming to the homes of Hindus. The effort is an attempt to close relationships and establish communication so that Hindu unity can be closely intertwined. In addition, the existence of routine meetings will be able to arouse a sense of brotherhood and unity of purpose to glue back the Hindu community in Menjing. The union according to Marx (Hardiman, 2009: 125) is a social action that is built on cooperation to achieve the desired goal.

Kerta Loka Temple in Menjing is a temple that is not only functioned as a medium of worship but also functions as a gathering place for Hindus to be able to strengthen relations with one another. This fact provides development in the use of temples that are not only performed as a holy place for worship but are also utilized by a series of religious social activities. The usage of the temple as a place to stick the solidarity of the Hindu community in Menjing according to Wiana (2004: 79) explicates that Hinduism has a really deep and multidimensional concept, therefore, the temple is not merely of a religious dimension, but also has a sociological dimension that can unite society in social and religious.

A similar sentiment was also conveyed by Indradewi, who in her research on the shifting function of temples in Bali confirmed that besides the temple as a place to hold religious ceremonies, the temple was also used as a medium in bonding brotherly relations (Indradewi, 2016: 205). This is the basis of the establishment of the Kerta Loka Temple in Menjing which is not only a place of worship but can also be used as a medium in social activities to strengthen relationships between religious communities. Kerta Loka Temple as the centralization of Hindus in Menjing is a symbol of the unification of ideology and identity that is built based on the mission to revive Hinduism in the future.
Utilization according to Titib (2003: 91) is a representation of the ideology of the temple as a fortress that guards the community. In line with this for the Hindu community in Menjing Pura Kerta Loka is a fortress in the material dimension to carry out social religious activities. This centralization, according to Segara (2015: 196), is the management of social capital in the religious dimension that is run coherently with the needs of the Hindu community in Menjing.

\subsubsection{Religious Learning through the Extension System}

The role of counseling for the Hindu community in Menjing is an endeavor to strengthen the unity of the people and the inculcation of Hindu religious values. In this situation, it becomes a challenge for the instructors to increase their enthusiasm to be able to provide services to the people. Where according to Mukhibat (2015: 188) counseling as a medium for the transformation of values and religious knowledge (transformation of values and knowledge). It plays a pretty significant role in creating a peaceful and harmonious life for the community. Likewise, for the Hindu community in Menjing, there is a counseling in addition to functioning as a learning process but also used to maintain the togetherness and solidarity that they have so that in the midst of the majority Muslim group, the existence of the Hindu community in Menjing can still be maintained in peace and harmony.

The building of collective awareness through a counseling system to the Hindu community in Menjing is a joint task that is not only given to local extension agents but strengthening from various parties is also required. Because with the togetherness in providing inculcation of religious teachings, it then will be able to provide psychological reinforcement that the Hindu community has social concern for others. This was also conveyed by Ulum (ed. 2015) that the provision of counseling is a shared responsibility as religious people who not only deliver spiritual messages of religious 
teachings but also with action as an obligation. In line with Ulum's view, counseling conducted in Menjing itself is inseparable from the help of various parties, this is demonstrated by the commitment of religious leaders in Bali to participate in administering counseling and even to build Palinggih in Kerta Loka Temple in Menjing.

The existence of assistance in religious counseling from religious leaders and institutions, namely IHDN Denpasar as conveyed is a strengthening of the religious life felt by the Hindu community in Menjing. Psychologically, religious teachings are carried out by giving dharma wacana to the people after the prayer, and materially the community is built a palinggih as a medium in the worship system to Ida Sang Hyang Widhi Wasa. The value of the spirit of togetherness makes the Hindu community in Menjing even more firm and confident that this religious counseling is not only as a strengthening of sradha bhakti but as a form of social concern for the existence of fellow people to build quality human resources by strengthening understanding of Hindu religious teachings.

\subsubsection{Habitual Worship to Strengthen Sradha Bhakti}

For the Hindu community in Menjing, the strengthening of religious mentality is not only begun with counseling but also carried out with the spirit of encouraging faith by conducting daily prayers at the Kerta Loka Temple. Worship is a manifestation of sradha and bhakti, one of which characterizes the existence of Hindu society in Menjing as a religious society and still maintains its existence in society. The situation is further used as a moment filled with dharma wacana to establish Hindu religious values. There is a commitment to advancing togetherness which is not only in the spiritual dimension but also socially and individually as internal reinforcement of Hindu society in Menjing. The balance of religious life in the spiritual and social dimensions in Menjing is strengthened by the view of Dhavamony
(2017: 172) which states that Vedic worship or rituals are not only aimed at connecting between the metaphysical world and the human world but also to uplift and strengthen procedures relating to human relations that are intertwined in togetherness and harmony. The relationship between fellow Hindus in Menjing is getting stronger with the prayer of ngareboin as a day agreed upon as a time to hold prayers.

The revival of Hindu society by conducting prayers every Wednesday is to strengthen their religious life which is symbolized by the victory of the dharma against adharma in the history of the Galungan holiday mythology. Collectively, the Hindu community performs prayers and chants the puja mantras as a form of establishing their religious soul in order to get guidance from Ida Sang Hyang Widhi Wasa. This is according to Dhavamony (2017: 173) in his research showing that the practice of Hindu religious rituals is quite uncommon and distinctive, in addition to using offerings from natural elements, they further create offerings by reciting puja. That is what provides magical power to their shrines. In line with the dhavamony statement, Donder and Wisarja (2011: 219) asserted that by holding regular prayers and special days as a form of internal strengthening of Hindu society in Menjing, it would actually be able to arouse and present spiritual vibrations that increase positive energy which not only impacts on people but also the environment will be calmer and more harmonious.

The regular worship activities by the Hindu community in the Kerta Loka Menjing Temple are a symbolic capital that becomes a strength, not only internally but socially within the community. This shows that the religious dimension of the Hindu community in Menjing is getting stronger and carried out with an attitude that takes care of one another. in addition, to build a sense of family of Hindus in Menjing, after the prayer is continuously filled with having a meal together. In this case, religious rituals according to Nottingham (1994: 31) 
functioned as a media in maintaining the integrity of the community as active and ongoing efforts. The Nottingham statement points that the joint prayers made by Hindus in Menjing are nothing but representations of the efforts made to maintain the integrity and unity of the community which is carried out continuously as a legacy of a religious cultural system.

\subsection{Strategy for the Detention of Sradha Bhakti of Hindu in Menjing \\ 2.2.1 Increasing Social Capital through Community Empowerment}

Social capital is the initial capital owned by someone when viewed from his dimensions as a multidimensional creature. Social capital is structured into a pattern that is built on the utilization of social relations to get social opportunities or benefits in society. Utilization of social relations, in this case, is to build a network (networking) which will be used as an intermediary media to develop power over the goal to fight for the group. This has been done by the Menjing community that their social capital must be grown by creating networks that support one another. The need for developing social capital by involving Hindus in Menjing is a first step in building a potential to increase the Hindu presence in Menjing.

Forming social relations as a capital that encourages the existence of Hindu communities in Menjing is a media in reinforcing identity to be able to develop a relationship of mutual respect (recognition) that can generate conducive conditions to various interests and resources. The existence of this relationship according to Berger and Luckmann (2018: 43) is the utilization of human values that not only provide security but also guarantees for the sustainability of future activities. Strengthening social capital empowered by the Hindu community in Menjing was modeled into three systems, namely individuals, the Hindu community, and the wider community. Strengthening individually is an effort in building Hindu community competence through the education system. It means that it is hoped that the Hindu young generation in Menjing should receive an education that does not only reach the teaching school but is pushed up to universities. The Hindu community in Menjing has started to invest their social capital from education, that with education in the future they will be able to have a way to be able to form a better quality of themselves.

The enthusiasm for better change by the Hindu community in Menjing is an impetus for the increasingly complex needs of the future. Where competition arises not only in the majority or minority values but is also related to the academic competence of the person. This is what is now starting to be formulated by the Hindu community in Menjing by strengthening the education of the younger generation so that they get to know the outside world and obtain networks that will hopefully be useful for themselves and Hindus. The description is in line with Bourdieu's view as expressed by Fashri (2014: 108) that social capital built in the educational dimension is a process of structuring structures that refers to ways to know, organize, and understand the social world to develop the potential of the community in empowering itself as a concept of sustaining social and cultural dynamics.

Strengthening the Hindu community as social capital that is converted through community empowerment is as an effort to perpetuate and build social relations, as outlined in the implementation of ritual activities or religious social solidarity individually or collectively to be able to construct social ties in society. With the existence of a community as a Hindu community bond in Menjing will be more powerful in positioning the community in unity and togetherness in providing an understanding of the noble values that have been passed down by the previous ancestors. This mission is a process of identity that is expected to knock the hearts of people who have converted to become Hindus by seeing Hindu unity now more solid. 
The mission in restoring Hindu identity through community empowerment has shown results. It means that people in Menjing still spiritually carry out Javanese Hindu rituals which they had inherited even though now they are Muslim. The situation according to Abdullah (2015: 9) is a reproduction of identity as part of social control and self-identification that positions individuals or communities into a dynamic set of values. The event of an ideological struggle arising from rituals hidden in the midst of the Islamic identity that they still profess to prove that ideology as a religious capital places people on spiritual power that can thrill the deepest hearts. So according to Thompson (2014: 269), the action was an expression of intent (intentional exteriorization) that they actually felt in their hearts.

\subsubsection{Utilization of the Dynamics Political Society Probability}

The development of the dynamics of political society in the middle is the grouping of people into activities carried out in social life. This categorization refers to developments that have taken place in the Hindu community's participation in exploiting opportunities in the midst of changing political currents. The tendency to take advantage of these opportunities with regard to the political sphere is not only in the sense of gaining personal benefits but also in looking at opportunities to be able to enter into government administration regulations which can strengthen the unity of Hindu community groups in the Middle East.

The knowledge of Hindu society in making use of the situation in the midst of a changing political situation shows a symbiosis of mutualism. Where the strengthening of Hindu religious identity with the granting of access to the land of temple construction is also supported by the dynamics of politics in the struggle over the power of the government system. Utilization of the legislative election situation in Jing indicates the existence of strength of religious and political communities that support each other. The situation according to Lubis (2015: 137) is one of the techniques of political democracy to support the goals of religious substance which is able to make people's lives become integrative since the basis for action is the meaning behind religious messages. This proves that the dimension of the political sphere utilized by the Hindu community in Jinging was used for the benefit of Hinduism.

Community response in seeing the political dynamics that occurred from the new order to reform became a challenge that actually benefited the existence of Hindu society in Jinging. The freedom given to people to be able to democracy in the political system provides their free opportunities to determine the direction of choice. This opportunity is a manifestation of a balance system in the dynamics of political society from authoritarian to democratize.

The interrelationship between the dynamics of the political community and the religious community in the struggle for a position shows mutually beneficial cooperation. For the Hindu community to open up opportunities to build access and networks through political figures, it can provide a way to build a stronger society going forward. Access to cooperation and networks that are integrated into exploiting these opportunities in Blumer's view (Poloma, 2003: 172) is a social system that is moving toward balance or stability. This movement is a complementary pattern of community dynamics as a cultural system that contains values and symbols and personality systems of individual actors in strengthening minority community groups.

Blumer's view clearly shows that the struggle for a social class that was built by utilizing political figures is not merely understood for the benefit of individual actors, but rather a collective agreement which is a common goal of Hindu society in Jing. In sociological analysis, Alford (1995: 379) states that the struggle of Hindu minority groups is a political step taken to strengthen the social system of society in fighting for religious rights. This view is also 
in line with the thought of Suryawan (2010: 227) that the exploitation of opportunities for the dynamics of political society in the struggle for power in the network is an identity politics that can strengthen the ethnic identity of Hindu society that accompanies the development of democratic reforms in the government system. Therefore, the interrelated relationship between the religious community and the political community in this case especially the Hindu community in the middle can be interpreted as an action pattern variable that is formed from the interests and needs to be able to strengthen the Hindu community going forward.

\subsubsection{Integration of Cultural Dimensions as Regulations of Social and Religious Life}

The religious life of the pluralistic and multicultural Hindu community in Menjing confirms that religion and cultural systems are not singular but plural consisting of various religions with their respective cultural systems. However, historically the Islamization process that took place in Menjing has shifted the religious and cultural dimensions that are carried out by the Hindu community in Menjing. This is because the demonization (setsetanakan) of the community to be Muslim forms the Hindu cultural system considered a system of idols and infidels and must be abandoned. This fact is in line with the view of Mutua (2014: 587) where geographically Islam is the most widespread and also the most colonizing, universalist, and has a mission to spread religion; that is, they try to change the religion or belief of all human beings into their religion.

Hindu culture that appears as the identity of the Javanese Hindu community in Menjing in the new order appears as a contest that shows that the Islamization process is a cultural war. The term pagan and idolatry brought up by the Islamic community in Menjing shows demonization which according to Mutua (2014: 593) is a different belief assumption from the majority group of Islam as a demon that is forbidden by depicting the religion as superstitious, unscientific and without logic.

Sociological reality shows that the diversity shown by the Islamization process is an emotional aspect that affects the shallowness of religious beliefs that changes religious behavior and tends to be fanatical without meaning. In these circumstances, the emergence of a struggle for the religious and cultural dimensions in Menjing made it difficult for the position of the Hindu community to either move or keep their Hindu. The demographic developments that have occurred in Menjing indicate the integration of cultural systems that show religion and the implementation of different cultural systems. The point is the process of Islamization that makes them unite themselves into Islamic culture both from the way they dress, greetings, or the ritual system.

The integration of the cultural system is an effort to protect themselves from becoming conflicts that harm Hindu groups in the minority Menjing. In Thompson's view (2014: 274) the mechanism of integration of Hindu cultural systems into the form of Islam is existentially an ideology understood as a means of justifying the existence of authority systems and the ideology of Islamic cultural systems is understood as a distortion that justifies a system of class domination. The fact that the position of the Hindu community in Menjing can be understood as a code of interpretation used to save integrity whose provisions collectively provide the image and representation of minority groups in a saved situation.

This situation is in line with Mahendra's research (1997: 164) which asserts that the existence of such integration if analyzed sociologically is something that overlaps (polymorphous) against an ideology whose existence is different from its essence, but in an effort to maintain the essential ideology from an asymmetrical power relations routine and systematic situation can be justified. This is also supported by Ricoeur (Thompson, 2014: 275) which states 
that the cultural integration of the Hindu Muslim community is the ways in which the meaning (meaning) justifies the relations of domination, so that the asymmetric attitude of the minority group is an effort in strengthening internal group to stay afloat amid the dominance of the majority group. In this context, the cultural integration conveyed by Ricoeur for internal Hindu minority groups in Menjing is in line with Abdullah's view (2015: 171) understood as symbolic legitimacy which shows the tendency of social structuring which is implicitly understood as a discursive process laden with the needs of minority groups in maintaining their culture personally.

The openness of the cultural integration system in the religious dimension of the people in Menjing has become a balance of social and religious life. The phrase according to Adnan (1999: 134) is an open attitude to the proactive cultural dimension of the progress that is happening which is a demand that cannot be ignored and must be a common concern. The Hindu community in Menjing in the current democratic reform era still maintains the integration. This is a form of openness and not fanatical with other cultural systems that aim to build a harmonious life. Yet, on the other hand, it turns out that openness also becomes a unique phenomenon implicitly demonstrated by people outside Hinduism in Menjing. This phenomenon reveals that the system of cultural integration in addition to influencing the social system of society also influences the practice of religious rituals of the Islamic community in Menjing. This fact implicitly implies the integration of culture to open up the inner awareness of the people of their predecessors who were Hindus so that they are still spiritually bound by geneology, but not publicly demonstrated. This situation, according to Cassirer (1994: 104), places a Muslim community in Menjing called a vinculum substantial whose ancestors originate from the same religious dimension, namely Hinduism.

Strengthening the social and religious dimensions as a pattern of integration carried out by the Hindu community is a reformative strategy or way of survival to build religious harmony. The suitability of these conditions according to Setiawan (2017: 87) is a life extension that is utilized as a way to survive in accordance with the cultural and religious system that they believe in by adjusting to the surrounding environment. This is further supported by Daeng (2008: 44) which states that adaptation to the environment inhabited by certain social groups which are more majority must be shown by adjusting to the environment. As said by Gasset "I am I and my circumstances". So that the integration built by the Hindu community in Menjing aside from being an adjustment effort to survive and protect as a minority group with a united cultural form both in the way of dressing and in showing their identity is an interrelation between the units contained in an environment which is a social system. Therefore, this cultural integration ultimately forms a strong emotional bond of Hindu society and results in solidarity and mutual cooperation which is developed and maintained to avoid conflict.

\section{CONCLUSION}

The religious education embodied in the Hindu community is viewed as patterned in techniques and strategies as an effort to empower people. This attests that there is an attempt to preserve and defend Hinduism by the people with acculturation of the cultural system in order to avoid a conflict that would actually be detrimental. However, behind all of the slow rise of Hindu communities in the building of temples, sustainable counseling, and the existence of routine prayers in the Kerta Loka Temple are a strategic pattern and path in instilling militancy and sradha bhakti of Hindu communities in Menjing.

\section{REFERENCES}

Abdullah, Irwan. 2015. Konstruksi dan Reproduksi Kekuasaan. Yogyakarta: Pustaka Pelajar.

Adnan. Habib. 1999. Agama Masyarakat dan Reformasi Kehidupan. Denpasar: Balai Pustaka. 
Alford, R. R. 1995. Agama dan Politik. Dalam Rolan Robertson (ed). Terjemahan dari "Sociologi of Religion". [Penerjemah Achmad Fedyani Saifuddin]. Raja Grafindo Persada: Jakarta.

Berger, Peter L. \& Luckman, Thomas. 2018. Tafsir Sosial Atas Kenyataan: Risalah tentang Sosiologi Pegetahuan. Terjemahan dari: "The Social Construction of Reality: A Treatise in the Sociology of Knowledge". [Penerjemah Hasan Basari]. Jakarta: LP3ES.

Cassirer. Ernst. 1994. Manusia dan Kebudayaan: Sebuah Esei Tentang Manusia. Terjemahan dari "An Essay on Man". [Penerjemah Alois A. Nugroho]. Jakarta: Gramedia.

Daeng, Hans J. 2008. Manusia, Kebudayaan, dan Lingkungan Tinjauan Antropologis. Yogyakarta: Pustaka Pelajar.

Dhavamony, Mariasusai. 2017. Fenomenologi Agama. Terjemahan dari "Phenomenology of Religion". [Penerjemah A. Sudiarja. G. Ari Nugrahanta, M. Irwan susiananta, M. Mispan Indarjo, A. toto Subagya, C. Arda Irwan]. Yogyakarta: Kanisius.

Fashri, Fauzi. 2014. Pierre Bourdieu: Menyingkap Kuasa Simbol. Yogyakarta: Jalasutra.

Hardiman, Budi F. 2009. Мепијu Masyarakat Komunikatif: Ilmu, Masyarakat, Politik, dan Posmodernisme Menurut Jurgen Habermas. Yogyakarta: Kanisius.

Indradewi, A.A Sagung Ngurah. 2016. Pergeseran Fungsi Pura di Bali: Dari Ritual ke Pertemuan Politik. Denpasar: Jurnal Kajian Bali Vol. 06, No. 02.

Lubis, Ridwan. 2015. Sosiologi Agama: Memahami Perkembangan Agama dalam Interaksi Sosial. Jakarta: Prenada Media Group.

Mahendra, Yusril Ihza. 1997. "Problematika HAM, Pluralisme Agama, dan
Integrasi Nasional". Dalam Anshari Thayib, Arief Affandie, Hemawan Malik, Bambang Parianom (ed). HAM dan Pluralisme Agama. Surabaya: PKSK.

Mutua, Makau. 2014. "Penyebaran Agama dan Integritas Budaya". Dalam Tore Lindholm, W. Cole Durham, dan Bahia G. Tahzib Lie (ed). Kebebasan Beragama atau Berkeyakinan. [Penerjemah Rafael Edy Bosko dan M. Rifa'I Abduh]. Yogyakarta: Kanisius.

Nottingham, Elizabeth K. 1994. Agama dan Masyarakat: Suatu Pengantar Sosiologi Agama. Jakarta: PT RjaGrafindo Persada.

Redana, I Made. 2000. Elit Agama Dan Perubahan Kewangsaan Di Kalangan Masyarakat Bali. Tesis. Yogyakarta: Universitas Gadjah Mada.

Setiawan, Hendro. 2017. Manusia Utuh:

Sebuah Kajian atas Pemikiran

Abraham Maslow. Yogyakarta:

Kanisius.

Suryawan, I Ngurah. 2010. Genealogi Kekerasan dan Pergolakan Subaltern: Bara di Bali Utara. Jakarta: Prenada Media Grup.

Thompson, John B. 2014. Analisis Ideologi Dunia: Kritik Wacana IdeologiIdeologi Dunia. Terjemahan dari "Studies in the Theory of Ideology". [Penerjemah Haqqul Yaqin]. Yogyakarta: IRCiSoD.

Titib, I Made. 2003. Teologi dan SimbolSimbol dalam Agama Hindu. Surabaya: Paramita.

Ulum, Raudatul. (ed). 2015. Memahami Realitas Sosial Keagamaan. Jakarta: Puslitbang kehidupan Keagamaan Kementerian Agama RI.

Wiana, I Ketut. 2004. Bagaimana Umat Hindu Menghayati Tuhan. Denpasar: Pustaka Manikgeni.

Wisarja, I Ketut. 2007. Gandhi dan Masyarakat Tanpa Kekerasan. Surabaya: Paramita. 